Fall 2007

\title{
Teach my child, too: African immigrant parents and multicultural educators sharing culturally responsive teaching tips
}

\author{
Mary Ghong \\ Texas A\&M University \\ Lychene Saah \\ Texas A\&M University \\ Patricia J. Larke \\ Texas A\&M University \\ Gwendolyn Webb-Johnson \\ Texas A\&M University
}

Follow this and additional works at: https://digitalscholarship.unlv.edu/jpme

\section{Repository Citation}

Ghong, Mary; Saah, Lychene; Larke, Patricia J.; and Webb-Johnson, Gwendolyn (2007) "Teach my child, too: African immigrant parents and multicultural educators sharing culturally responsive teaching tips," Journal of Praxis in Multicultural Education: Vol. 2: No. 1, Article 4.

DOI: 10.9741/2161-2978.1023

Available at: https://digitalscholarship.unlv.edu/jpme/vol2/iss1/4

This Article is protected by copyright and/or related rights. It has been brought to you by Digital Scholarship@UNLV with permission from the rights-holder(s). You are free to use this Article in any way that is permitted by the copyright and related rights legislation that applies to your use. For other uses you need to obtain permission from the rights-holder(s) directly, unless additional rights are indicated by a Creative Commons license in the record and/ or on the work itself.

This Article has been accepted for inclusion in Journal of Praxis in Multicultural Education by an authorized administrator of Digital Scholarship@UNLV. For more information, please contact digitalscholarship@unlv.edu. 


\section{Teach My Child, Too: African Immigrant Parents and Multicultural Educators Sharing Culturally Responsive Teaching Tips}

\section{Mary Ghong, Lychene Saah, Patricia J. Larke, and Gwendolyn Webb-Johnson}

A demographic shift has initiated many changes in school districts in the United States. Schools are trying to address the needs of a school-age population that is culturally, linguistically, ethnically, and economically diverse (CLEED). However, there is one group that continues to be "invisible" in our schools, and that group is students of new African immigrants. These children come from a continent of great diversity that includes many countries (Speer, 1995). They come from the North to south of the Sahara and have a phenotype that ranges from White Africans to Black Africans. They come from Anglophone- to Francophone-speaking countries and from various socioeconomic levels, from radical to moderate countries. New African immigrants come to America, like many other immigrants, to seek a new life and to get away from the social, political, and economic turmoil that plagues their country. Their plight is very similar to most immigrants; yet, they seem to be forgotten in the schools.

While the phenotype has caused many teachers to identify new African immigrants as African Americans, many parents believe that their children's multilingual abilities and cognitive abilities often go unnoticed. Many parents of African immigrant children are frustrated and, in response, find themselves providing teachers with strategies to assist in educating them about their children. Thus, the purpose of this article is to: (1) discuss African migration to the U.S., and (2) provide culturally responsive teaching tips that can assist

\footnotetext{
Mary Gong is a doctoral student in the Department of Teaching, Learning and Culture, Texas A\&M University. Her research interest is in reading and multicultural education. Lychene Saah is a doctoral student in the Department of Teaching, Learning and Culture, Texas A\&M University. Her research interests are educational issues of new African immigrants and multicultural education. Patricia J. Larke is a Professor in the Department of Teaching, Learning and Culture, Texas A\&M University. Her research interests are educating teachers for diverse classrooms and issues related to teachers of color. She was the recipient of the 2004 G. Pritchy Smith's Multicultural Educator Award. Gwendolyn Webb-Johnson is an Assistant Professor in the Department of Educational Administration and Human Resources, Texas A\&M University. Her research interests include the disproportional number of African American students in Special Education and culturally responsive teacher development.
} 
teachers to work more effectively with students who are new African immigrants.

\section{African Migration to the United States}

When Europe halted the influx of African immigrants, the U.S. opened its doors by making it easier for immigrants to legally come into the U.S. (Yiman, 1990). Wynn (1995) distinguishes that the $20^{\text {th }}$ and $21^{\text {st }}$ century immigration from Africa to America is very different from that of earlier centuries. Migration today is not the result of force but rather due to voluntary decisions by the African expatriates. Wynn (1995) noted that the 1980 Refugee Act accelerated an influx of refugees from many countries into the U.S. In fact, according to Omar (2005), there are approximately 50,000 arrivals of new African immigrants annually. This increase is due in part to a lottery system that allows many Africans to receive visas to migrate into the U.S. This program allocates more than 25,000 visas for Africans each year. Gordon (1998) calls the influx the 'New Diaspora' and states that a sizable African community of more than 500,000 now resides in the United States. Some reside as permanent residents, naturalized citizens, and others as native-born citizens. Adugna, (1998) stated that new African immigrants are highly educated, urbanized, and have one of the highest per capital incomes of any immigrant group. Similarly, Gordon (1998) shares the same opinion with Adugna (1998) that about 88 percent of adults who migrate to the U.S have a high school education or a higher education degree.

The influx of African immigrants from countries such as Ghana, Congo, Rwanda, Cameroon, South Africa, Kenya, Sierra Leone, and Nigeria are on the rise each year. According to the 2000 Census, African immigrants make up one million of the U.S. population. Although the new African immigration is just about 3\% of all immigrants, their issues are worthy of educational discussions. New African immigrants are forced to deal with political, psychological, social, and cultural issues in the communities where they live and in the schools their children attend. Often they face cultural shocks in schools.

\section{Cultural Differences}

There are a lot of cultural differences between the U.S. and the countries where new Africans once lived. These differences are in ways people think, reflect, and do things (Nii-Amoo, 1997). While new African immigrants are more communally oriented, they find that many in the U.S. are more individualistic. Most Africans come from communities where sharing is an integral part of their lives. These students come from a community that epitomizes caring. This care is demonstrated in a village community environment where togetherness is 
valued, and sharing of Kola nut in gatherings is perceived as a sign of peace and love (Achebe, 1996). Thus, Africans' valuing of respect, care, and community is seen as a prestigious commodity that begins to dwindle when it is not reciprocated, especially for African immigrants in U.S. schools. Community support of the "good neighbor" concept is fundamental to African immigrants. It is disturbing to them when some Americans say they do not have a culture, while others identify their culture only as language (Spring, 1997).

Many African immigrant students are multilingual speakers. For example, in Nigeria with a population of approximately 80 million people, there are three main languages: Ibo, Hausa, and Yoruba. While in Cameroon there are about 260 dialects. Therefore, a typical Cameroonian child will speak a dialect, the pidgin language, and then learn to speak the official languages of English or French. Yet, when these students come to the U.S., their multilingual abilities are not valued in schools. Instead, they are faced with negative perceptions about accents and their "different" English pronunciations. Accents should not be used to penalize the African immigrants if communication is not impeded (Apraku, 1996). Also, they are expected to show verbal usage when many African immigrant children are raised in environments where children are taught that they should be seen, not heard, and that talkative children are looked upon as disrespectful; progress will be at stake. (Arthur, 2000).

If educators do not have prior knowledge about differences in cultural values, it could lead to misjudgment of students' abilities that could result in academic failure or inappropriate grade or special education placement. In fact, one study reported that out of 50 African immigrant parents interviewed, 40 of them $(80 \%)$ indicated that their children were placed in a grade level behind because of the language differences when they first arrived in the U.S. (Arthur, 2000). The parents also shared the frustration that they experienced with teachers when they expressed dissatisfaction with their children's progress although these same children were considered gifted in their former school in Africa. According to Arthur (2000), if educators do not have prior knowledge of their students' differences in cultural values, then these students' progress can be impeded.

Additionally, educators should know that there are marked differences between African immigrant students not born in the U.S. and African American students who have lived all their lives in the U.S. African immigrant students do face psychological and social problems in their schools. They may feel a sense of loss, anxiety, sense of being a non-person, of trying to adapt to being separated from families and former communities. Other cultural differences are found in the style of greetings, concept of eye contact, and different concepts of time. These differences bring much conflict in homes as immigrant parents try to maintain family values and internalize the new concepts with their children. Thus, the next section of this article will focus on teaching tips that are grounded 
in culturally responsive teaching in hopes of providing educators with ways to respond to new African immigrant students who are experiencing cultural differences.

\section{Culturally Responsive Teaching Tips for New African Immigrants}

\section{Culturally Responsive Teaching}

Culturally responsive teaching (CRT) is based on the work of our colleague, Geneva Gay. Gay (2002) defines CRT as:

Using the cultural characteristics, experiences, and perspectives of ethnically diverse students as conduits of teaching them more effectively, it is based on the assumption that when academic knowledge and skills are situated within lived experiences and frames of reference of students, they are more personally meaningful, have higher interest appeal and are learned more easily...As a result, the academic achievement of ethnically diverse students will improve when taught through their own cultural and experimental filters (p. 106-107).

For the purpose of this article we are using three components of culturally responsive teaching (Gay, 2000; 2002). These components are cultural competence, critical consciousness, and engaging academic success.

\section{Cultural Competence}

Culturally competent teachers include cultural characteristics, experiences, and perspectives of ethnically diverse students as conduits of teaching. Teachers who engage in cultural competence participate in the following behaviors or activities. These teachers:

A. appreciate and celebrate diversity among all new African immigrant students. They realize that these students have experiences to share with the entire class and provide venues for them to share their experiences that are more than cultural awareness days;

B. integrate students' knowledge and cultures into the curriculum. Remember that Africa is a continent and not a country. West Africa and East Africa are not only thousands of miles apart, but many countries have their own language as well as other cultural differences. Their knowledge about African culture is integrated into the curriculum and not as an addendum; 
C. when making an assessment, they use a variety of learning and assessment techniques that are culturally sensitive to provide the best academic assessment possible (Pang, 2001);

D. utilize skills, abilities, and strengths of new immigrant students to promote higher academic standards. Many students are multilingual and come from families that are highly educated. Thus, they find ways to capture the strength of these multilingual students;

E. realize that African immigrant children may refuse to participate in oral discussions because they fear others may ridicule their accent. Often when students do not talk like "other American students," they feel embarrassed and may become silent in the classroom. These teachers demand that students listen and show respect for differences that are not deficits, just differences, and affirm these differences as distinctiveness;

F. realize that basic English words have various synonyms. For example, sneakers, oxford, tennis shoes, scoopies, and canvas are all various names for athletic shoes. An African immigrant child may call these "scoopies" which is common in parts of Africa. They understand that words may have multiple meanings and seek opportunities to enhance learning for both teacher and students to learn these meanings.

\section{Critical Consciousness}

These teachers help students develop a broader perspective of the sociopolitical consciousness and the tools to critically analyze societal relationships. These teachers understand the sociopolitical context of the countries from which their students immigrated. These teachers:

A. know that special education placement is not an equitable placement for most new African immigrant students. This is a common practice when students enter U.S. schools. Teachers must not equate limited English skills with special education. These teachers seek appropriate placement instruments that are culturally relevant;

B. avoid linguicism (devaluation of one's linguistic heritage) and acknowledge global variations of standard English (Alidou, 2000). They realize that if the culture is valued, the language is valued, and the child is valued. There is no separation of language or culture from children (Larke, 2000);

C. research African immigrants' cultures and establish rapport with parents. They seek ways to learn from parents and new immigrant students. Parents are the child's first teacher and learning from them can enhance the child's 
learning environment. Parents can provide accurate information about the culture as well as information relevant to their child's learning style;

D. seek an understanding of the sociopolitical, educational, and economic factors that have impacted their migration decision. These teachers realize that some new African immigrant students may be survivors of war, torture, and abuse. They are extremely sensitive to students' feelings and involve school counselors and parents when necessary.

\section{Engaging Academic Success}

These teachers improve ethnically diverse students' academic achievement by teaching them through their own cultural and experimental filters. These teachers:

A. avoid stereotypical practices and treat each immigrant child uniquely. They know that they are not African American students, but new African immigrant students. These teachers realize that many do not know anything about being African American nor the stereotypes that are associated with African Americans;

B. build relationships of trust with students and persist until academic excellence is attained (Gay, 2000);

C. avoid instructional racism through selection of teaching materials, perceptions, and interactions of people of color (Larke, Webb-Johnson, Anderson \& Rochon, 1999). These teachers are cognizant that Africa is five times the size of the U.S. and they select authentic maps that denote the differences;

D. provide a nurturing and supportive classroom environment for immigrant children to take risks in acquiring new academic skills. They provide students ample time to learn English since many have multilingual skills and have demonstrated the skills necessary to master multiple languages;

E. understand cultural differences in parent-teacher roles. In Africa, parents generally trust all educational decisions to teachers and withhold from interfering with school policies and practices. They involve parents and implement ideas to improve the instruction;

F. place students on "catching-up" tracts when necessary. Academic gaps are common in African students who have experienced wars prior to immigrating to the U.S.;

G. use an abundance of concrete examples and ESL strategies when necessary to increase their English skills and competency; 
H. treat the new African immigrant child with compassion and respect. They expect only the best and render only the best. These teachers have high expectations with attitudes, behaviors, and skills to promote academic excellence.

\section{Conclusion}

New African immigrants suffer from "invisibility." There is a need to educate teachers to work with this group. A story by an African immigrant parent and graduate student in multicultural education best captures this need. She used her critical lens of multicultural education to highlight the need for teachers to be informed about new African immigrants. She states that:

A crucial problem of African immigrants has been the aspect of language. Like me, most African immigrants have dialects other than English. In Cameroon for instance, there are 260 dialects and a child is able to speak about four languages while growing up. In Nigeria, the Ibo, Hausa, and Yoruba dialects are spoken ubiquitously. It is thus, difficult to speak English, like English native speakers because of the interference of the mother tongue languages. Yet, we are able to communicate.

Language is believed to be an embodiment of culture. Yet, according to Darder (1991), language is used to understand a person's histories and social realities. Language is used to bargain, assert, affirm, negotiate, and to express one's emotions and thoughts. It is most embarrassing then when African children are rebuked because of their accents or told that they do not speak correctly and cannot be understood.

Most African immigrants are greeted with phrases, such as, "You have an accent;" "Where do you come from?" Others would openly tell the immigrants that they do not understand when they talk because of a "strong accent." All these cynical remarks are made because the U.S. society expects everyone to be "Americanized" (Nii-Amoo, 1997).

Some African children in schools have been termed less intelligent because of their accent. In fact, some students have been placed in special education because of their accents (Campbell, 1996). This was the experience with Zuzu, an African student who had constant problems in school because he had an accent. His teachers did not understand him. In fact, the teachers proposed that he be transferred to special education. It brought a lot of psychological torment to that family. The family was educated enough to struggle against the placement of Zuzu in a special education class.

During an interview with some African families from Nigeria, Tanzania, Somalia, Kenya, Ghana, and Senegal, we found that they shared 
similar experiences with their children and the school system as noted in studies (Arthur, 2000). They despised the idea of a special education class, which was a new phenomenon. Several immigrant parents shared how they were told that their child would be placed in the special education class. At first, they were happy because they thought it was indeed a 'special' class in the true sense of the word and expressed their sense of happiness. Little did they know what special education meant for their children? They thought that special education meant a special school, because in their culture there is only one school that is inclusive for all children.

In summary, we shared results from a few studies and stories about the plight of African immigrants. We want educators to be knowledgeable about new African immigrants and some of the "invisibility" they face in schools. It is within this framework that culturally responsive teaching will make the African immigrant student become visible, and teachers will respond to the quest of parents of new African immigrants to "Teach my child, too."

\section{References}

Achebe, C. (1996). Things fall apart. London: Heinemann Publishers.

Adugna, G. (1998). African immigrant in the modern era. Retrieved August 20, 2006 from http://www.clis.umd.edu/-mddlmddl/791/communities/html/africanmd. html

Alidou, H. (2003) Language policies and language in Francophone Africa: A critique and a call to action. In S. Mokoni, G. Smitherman, A. Ball \& K. Spears (Eds.).

Black linguistics: Language, society, and politics in Africa and the Americas (p.105-117). New York: Routledge

Apraku, K. (1996). Outside looking in: An African perspective on American pluralistic society. Westport: Praeger Publishers.

Arthur, J. (2000). Invisible sojourners: African immigrant diaspora in the United States. Westport: Praeger Publishers.

Campbell, D. D. (1999). Choosing democracy. A practical guide to Multicultural Education. Prentice-Hall Inc.

Darder, A. (1991). Culture and power in the classroom. A critical foundation for Bicultural Education. New York, NY: Bergin and Garry.

Gay, G. (2000). Culturally responsive teaching: Theory, research \& practice: New York: Teachers College Press.

Gay, G. (2002). Preparing for culturally responsive teaching. Journal of Teacher Education, 53, 106-107.

Gordon, A. (1998). The new diaspora: African immigrant to the United States. Journal of Third World Studies, 35, 79-102.

Graves, M., Juel, C., \& Graves, B. (2007). Teaching reading in the $21^{\text {st }}$ century. Boston, MA: Pearson Education, Inc.

Larke, P.J., (2000, February). One multicultural education graduate class: Merging research, theory and practice to prepare teacher educators for the new 
millennium. A paper presented at the Association of Teacher Educators Annual Meeting. Orlando, FL.

Larke, P.J., Webb-Johnson, G., Rochon, R., \& Anderson, M. (1999). Healing the wounds of instructional racism. In. N. Quisenberry \& J. McIntyre (Eds.) Racism from a healing perspective (pp.49-66). Olney, MD: Association of Teacher Educators and Association for Childhood International.

Nii-Amoo, D. F. (1997). Assimilation differences among Africans. America Social Forces, 76, 527-546.

Omar, S. (2005). Diversity and transformation. African Americans and African immigration to the U.S. Retrieved April 10, 2006 from www.migrationinformation,org/usfocus

Pang, V. (2001). Multicultural education: A caring-centered, reflective approach. New York, NY: McGraw Hill.

Speer, T.L. (1995). The newest African Americans aren't Blacks. American Demographics, 6, 9-10.

Spring, J. (19970). The American school, 1642-1996. Boston, MA: McGraw Hill Co.

Yiman, A. (1990). Social development in Africa: Methodological perspectives 1950 and further 1985 prospects. Retrieved May $15 \quad 2006$ from http://oriole.umd.edu/ mddlmddl/791/communities/html/africanmd.html

Wynn, R. (1995). African immigration in the modern era. Retrieved May 152006 from http://oriole.umd.edu/ mddlmddl/791/communities/html/africanmd.html 